\author{
https://doi.org/10.52449/1857-4114.2020.36-2.05
}

CZU: 371.136+378.1:612

\title{
CRITERIA FOR ASSESSING STUDENTS' PROFESSIONAL COMPETENCES IN THE "HUMAN PHYSIOLOGY AND MOTOR ACTIVITY" MODULE
}

\author{
Gîrlea Natalia , ORCID: 0000-0002-0909-351X \\ ${ }^{1}$ State University of Physical Education and Sports, Chisinau, Republic of Moldova
}

\begin{abstract}
The knowledge of the physiological processes and the mechanisms of vital activity of the organisms gives the possibility to the future specialist in the field of physical education and sports to understand the causes of the appearance of the complicated functional states of the organism characteristic for the muscular activity. This will allow them to rationally distribute physical effort and rest in both physical education and training classes, to forecast short-and longterm sports results.

The results of the theoretical-praxiological analysis of the instructive-educational process within the disciplines provided by the curriculum of the faculties of physical education and sports show that in this field:

- a specific evaluation system does not work, therefore it is not known what level of professional competencies and what didactic competencies the student actually has;

- the desire of students to train and use their professional skills in quality sports is more declared, it is not supported by appropriate actions [6, 15, 16].

The theoretical study of the problem of training-development of professional skills identified different approaches to its classification and typology: some real results-oriented, and others with confusing orientation in this regard, neither of the two types of approaches, at least in the field of physical education, not being sufficiently argued from a systemic point of view.
\end{abstract}

Keywords: physical effort, physiological process, professional competence, educational content, sample.

Actuality of the research. The problem of preparing the students of the faculties of physical education and sports regarding the professional-pedagogical competence was approached by authors such as C.H. Daniel [15]; В.И. Baidak [14], N. Guidea [1]; V.Oprescu [5]; O.E. Афтимичук [11]; М. Gönzi-Raicu [2]; N.Tomşa [8]; C. Nanu [3]. However, the training of professional competence in students of physical and sports faculties has not yet become a permanent and continuous educational objective and practice. In the same context, competence, as a synthetic unit of the three defining behaviors - knowing, knowing how to do, knowing how to be, achieves knowledge at the highest level, including through the formation-development of personality structures such as skills, motivations and attitudes (in a broad sense) $[12,4]$.

Competence is formed by exploringcapitalizing on the educational content of each type of education and by the simultaneous exercise by the subject of learning of complex activities of acquisition (knowledge), doing (skills) and expression (attitudes).

First of all, competence calls for the organization of a set of resources: knowledge, experiences, schemes, automation, capabilities, savoir-faire of different types, etc. The communicative context becomes decisive in the realization of pedagogical behaviors, 
conceived not only as a device of pedagogical interactions, but as an object of teachers' concerns regarding the professional development of the pedagogue. The formation of professional competence in future student-pedagogues responds, therefore, to the principle of professional approach to education and completion of the register of specialized competencies of the teacher [9].

The formation of the system of competences, especially of the professional one at the students of the physical education faculties, becomes possible by teachinglearning-evaluating the disciplines of the pedagogical module and requires, on the one hand, the formation of capacities, skills, abilities, written professional attitudes, didactic discourse, and on the other hand, the development of relational behaviors, thus facilitating the integration of the physical culture system (PCS) in the professional activity [9].

The major problem solved lies in:

- insufficient investigative approach to the issue of training of professionalpedagogical skills in the field of physical education and sports, which may cause impediments in the training of students, because professional competence is the basis of the professional framework of university teachers in this field;

- the values of pedagogical competence communicativeness, appreciation of contents, research and improvement of educational experiences, student knowledge, creativity, empathy, educational management, absolutely indispensable for a school teacher;

- the tendency to ensure the quality of higher education by training professional skills $[13,7,10]$.

The purpose of the research is to determine and argue the technology / criteria for assessing the professional skills of students of physical education and sports in the module "Human physiology and motor activity".
Research methods: theoretical analysis and generalization of data from the literature, pedagogical observation, socio-pedagogical survey, testing method, pedagogical experiment, mathematical-statistical methods for processing and interpreting the results obtained.

Organizing and conducting research. In order to argue the need to develop the technology for evaluating the professionalpedagogical competencies of the students of the faculties of physical education and sports during the 2017-2018 academic year, we conducted a sociological survey.

The results of the analysis of the sociological survey conducted with teachers, coaches and students of physical education and sports, allowed us to determine the implementation period of the curriculum in the module "Human Physiology and Motor Activity" in the first semester, second year of studies, being oriented towards the formation of specific competencies in the process of organizing and conducting physical education lessons within the pedagogical practice.

The methodological elaborations of the optional module "Human physiology and motor activity" were implemented in the study process in the first year, first semester, academic year 2017-2018. The process of skills training included the organization of a set of types of lessons, which took place with two groups of students: the experimental $(n=15)$ and the control $(n=15)$.

According to the structure and content of the optional module "Human physiology and motor activity" in the experimental group all lessons were conducted according to the requirements of the methodological elaborations proposed by us, and in the control the lessons were taught according to the requirements of the study disciplines "Human physiology" and "Physiology of physical education and sports" according to the curricula of the faculties of physical education and sports. 
In order to establish the level of homogeneity of the experimental and control groups, we evaluated the level of acquisition of the theoretical knowledge and practical- methodical skills necessary for specialists in the field of physical education and sports (Table 1).

Table 1. Results of the evaluation of the level of theoretical training of students regarding the training of professional skills at the initial and final stage, $n=15$

\begin{tabular}{|c|c|c|c|c|c|}
\hline \multirow{2}{*}{$\begin{array}{l}\text { No. } \\
\text { crt. }\end{array}$} & \multirow[t]{2}{*}{ Knowledge-skills-attitudes } & \multicolumn{2}{|c|}{$\begin{array}{l}\text { Initial results } \\
\text { (note) }\end{array}$} & \multicolumn{2}{|c|}{$\begin{array}{c}\text { The final } \\
\text { results (note) }\end{array}$} \\
\hline & & \multicolumn{4}{|c|}{ Groups } \\
\hline \multicolumn{2}{|r|}{ Contents } & $\mathrm{E}$ & $\mathrm{M}$ & $\mathrm{E}$ & $\mathrm{M}$ \\
\hline 1 & $\begin{array}{l}\text { History of the development of physiology. } \\
\text { Define the object of study of general physiology. } \\
\text { Blood and hematopoiesis. Blood and its changes } \\
\text { in physical exertion. }\end{array}$ & 6,01 & 6,14 & 9,22 & 8,17 \\
\hline 2 & $\begin{array}{l}\text { Blood and lymph circulation. Cardiovascular } \\
\text { adaptive changes in physical exertion. } \\
\text { Breathing. Adaptive changes in respiration in } \\
\text { physical exertion. }\end{array}$ & 6,11 & 5,86 & 9,45 & 8,21 \\
\hline 3 & $\begin{array}{l}\text { Digestion and absorption. Nutrition and physical } \\
\text { activity. Energy metabolism in effort. }\end{array}$ & 6,02 & 5,89 & 9,26 & 8,32 \\
\hline 4 & $\begin{array}{l}\text { Excretion processes. The physiological } \\
\text { mechanisms of the body's thermoregulatory } \\
\text { processes. Endocrine secretion. Adaptive } \\
\text { endocrine changes in physical exertion. }\end{array}$ & 6,25 & 6,34 & 9,25 & 8,61 \\
\hline 5 & $\begin{array}{l}\text { Central nervous system (CNS). Sensory } \\
\text { systems. Nervous system and sensory systems. }\end{array}$ & 5,98 & 5,82 & 9,20 & 8,21 \\
\hline 6 & $\begin{array}{l}\text { Upper Nervous Activity (UNA). The } \\
\text { neuromuscular system. Physiology of muscle } \\
\text { contraction. }\end{array}$ & 5,98 & 5,94 & 9,18 & 8,56 \\
\hline 7 & $\begin{array}{l}\text { The physiological bases of voluntary } \\
\text { movements. Adaptation to muscle activity and } \\
\text { physiological reserves of the body. Optimization } \\
\text { of sports activity. }\end{array}$ & 5,76 & 6,16 & 9,11 & 8,36 \\
\hline 8 & $\begin{array}{l}\text { Classification and physiological characteristics } \\
\text { of physical exercises. Physiological } \\
\text { characteristic of the state of the body in sports } \\
\text { activity. }\end{array}$ & 5,94 & 6,07 & 9,58 & 8,18 \\
\hline 9 & $\begin{array}{l}\text { Physiological bases of sports training. The } \\
\text { physiological bases of the development of motor } \\
\text { qualities. }\end{array}$ & 6,08 & 5,95 & 9,19 & 8,37 \\
\hline 10 & $\begin{array}{l}\text { Classification of training efforts. Principles of } \\
\text { sports training and their reasoning. Physiological } \\
\text { argumentation of training, sports orientation and } \\
\text { selection of young athletes }\end{array}$ & 6,25 & 6,12 & 9,32 & 8,31 \\
\hline
\end{tabular}


Data analysis and interpretation. The level of mastery of theoretical knowledge was determined as a result of the current assessment of students. The practicalmethodical skills were evaluated based on the development by the students of a laboratory lesson (with the objectives, contents and forms of organization indicated by us). The results of the evaluation of the level of preparation of the students for the formation of the professional competences are presented in Table 1, based on the 10-point system.

The average marks per group for assessing the knowledge-skills-attitudes related to students' professional skills were 6.58 and served as a basic factor in determining their initial level of training, as well as in establishing the homogeneity of experimental and control groups.

Following the generalization of the survey data conducted with SUPES coaches and students, the aspects of evaluating the level of knowledge possession and specialized scientific sources allowed us to determine the criteria for evaluating the level of training of professional competence at the level of knowledge - to know, to be able, to possess, for each being determined a large number of criteria. From the multitude of criteria determined for each level, we selected 5, which are of increased interest in this researched topic.

Thus, in order To know the fundamental motor physiological principles and the classification of the effort, 5 main criteria were formulated that define it:

1. Morphofunctional indices of the controlled training state during the relative rest state; of the dosed effort, of the maximum effort;

2. Functional changes of organs and systems caused by sports muscle effort;
3. Characterize the particularities of the fatigue process when performing different sports tests;

4. Physiological classification of motor skills;

5. Morphofunctional changes during intensity exercises: maximum, submaximal, high, moderate.

In order To be able to define and apply morphofunctional indices in free state and after physical effort, the following criteria were formulated:

1. Determine the blood pressure and the factors that determine it. Changes in blood pressure when performing muscular efforts of different intensity;

2. Interpret the difference between a venous artery and the notion of oxygen-volume of blood;

3. Motor units as basic functional elements of the neuromuscular system. Muscle fibers and their types (slow, fast);

4. Physiological characteristic of recovery processes;

5. Determine the indices of elastic explosive force by investigating the power and expansion by a vertical jump (Sargent test).

In the same order of ideas for To possess the physiological aspect of the states of the organism and the restoration processes were selected:

1. Cardiac efficiency research using systolic volume and minute-volume indices (Star method);

2. Physical work capacity control methods (PWC Test -170, Harvard Test);

3. Methods for controlling the functional stability of the vestibular analyzer;

4. Controlling the phase structure of the restoration process and optimal rest periods;

5. Determining the athlete's ability to repeat succinctly, a maximum effort $5 \times 6$ test of maximum repeated effort. 
Table 2. Comparative analysis of experimental data representing the level of possession of professional competence at the initial and final stage (notes), $(n=15)$

\begin{tabular}{|c|c|c|c|c|c|c|}
\hline \multirow[b]{2}{*}{$\begin{array}{l}\text { No. } \\
\text { crt. }\end{array}$} & \multirow[b]{2}{*}{ Criteria } & \multirow{2}{*}{$\begin{array}{l}\text { Groups } \\
\text { and } \\
\text { statistics }\end{array}$} & \multicolumn{4}{|c|}{ Statistical indicators } \\
\hline & & & $\begin{array}{l}\text { Initial } \\
\bar{X} \pm m\end{array}$ & $\begin{array}{l}\text { Final } \\
\bar{x} \pm m\end{array}$ & $\mathbf{t}$ & $\mathbf{P}$ \\
\hline \multirow[t]{4}{*}{1} & \multirow{4}{*}{$\begin{array}{l}\text { To know the fundamental } \\
\text { motor physiological } \\
\text { principles and the } \\
\text { classification of effort }\end{array}$} & M & $7,16 \pm 0,25$ & $7,40 \pm 0,24$ & 1,04 & $>0,05$ \\
\hline & & $\mathbf{E}$ & $7,27 \pm 0,26$ & $8,18 \pm 0,22$ & 3,96 & $<0,01$ \\
\hline & & $\mathbf{T}$ & 0,30 & 2,44 & - & - \\
\hline & & $\mathbf{P}$ & $>0,05$ & $<0,05$ & - & - \\
\hline \multirow[t]{4}{*}{2} & \multirow{4}{*}{$\begin{array}{l}\text { To be able to define and } \\
\text { apply morphofunctional } \\
\text { indices in free state and } \\
\text { after physical effort }\end{array}$} & $\mathbf{M}$ & $6,97 \pm 0,26$ & $7,14 \pm 0,25$ & 0,71 & $>0,05$ \\
\hline & & $\mathbf{E}$ & $7,11 \pm 0,25$ & $8,20 \pm 0,20$ & 4,74 & $<0,001$ \\
\hline & & $\mathbf{T}$ & 0,39 & 3,23 & - & - \\
\hline & & $\mathbf{P}$ & $>0,05$ & $<0,01$ & - & - \\
\hline \multirow[t]{4}{*}{3} & \multirow{4}{*}{$\begin{array}{l}\text { To possess the } \\
\text { physiological aspect of the } \\
\text { states of the organism and } \\
\text { the restoration processes }\end{array}$} & M & $7,08 \pm 0,26$ & $7,29 \pm 0,24$ & 0,87 & $>0,05$ \\
\hline & & $\mathbf{E}$ & $7,12 \pm 0,25$ & $8,17 \pm 0,22$ & 4,77 & $<0,001$ \\
\hline & & $\mathbf{T}$ & 0,11 & 2,75 & - & - \\
\hline & & $\mathbf{P}$ & $>0,05$ & $<0,01$ & - & - \\
\hline
\end{tabular}

In Table 2 we represent the initial data of the evaluation criteria of the level of training the professional competence of the control and experimental groups. From the represented ones we observe that the integrative competencies To know the fundamental motor physiological principles and the classification of the effort to the 5 criteria that assess the knowledge of the students of the control group (CG) at knowledge level, the fundamental motor physiological principles and the effort classification were capitalized 7,16 (per group). Below, we have represented the integrative competence To be able to define and apply morphofunctional indices in free state and after physical effort includes the criteria for defining and applying morphofunctional indices in free state and after physical effort which were capitalized with an average per group of 6,97. Criteria pending integrative competence To possess the physiological aspect of the state of the organism and the recovery processes were evaluated with an average per group of 7,08. From those represented (Table 2) it is easy to see that the knowledge of the students of the
Experiment Group at the level of Knowing the fundamental motor physiological principles and the classification of the effort were capitalized with the average per group of 7,27. Thus, the criteria pending the integrative competence To be able to define and apply morphofunctional indices in free state and after physical effort that were capitalized with the average per group of 7,11 , and those that are part of the category To possess the physiological aspect of the states of the organism were appreciated with an average per group of 7,12 .

Generalizing these, we can say with certainty that the control group and the experiment group are homogeneous, this being demonstrated by the marks accumulated following the tests performed. In other words, these data being obtained allow us to carry out pedagogical experiments.

If we analyze comparatively from a statistical-mathematical point of view the results of the students' evaluation according to the 3 levels of appreciation of the competences "to know", "to be able", "to possess" in the control and experiment groups at the initial stage (Table 2), we observe that $t$, calculated 
for all evaluation criteria varies between 0,11 0,30 the value being lower than tabular $t$, which proves that the differences between the two groups are insignificant $(\mathrm{P}>0,05)$.

In Table 2 we have represented the final data of the evaluation criteria of the level of training of the professional competence of the control group easily, we can see that the criteria that assess the knowledge of the control group students in terms of knowledge of fundamental motor physiological principles and effort classification were used the average per group of 7,4. We also have represented here the criteria for defining and applying the morphofunctional indices in free state and after physical effort, that were capitalized with the average per group of 7,14, and the criteria for possessing the physiological aspect of the organism and recovery processes were appreciated with an average per group of 7,29.

The statistical and mathematical analysis of the experiment data shows that in most of the criteria for assessing the integrative competencies "to know", "to be able", "to possess" were obtained results that show that $\mathrm{t}$ calculated for all criteria varies between 0,71 - 1,04, lower than tabular $t$, which denotes insignificant differences $(\mathrm{P}>0,05)$ between the initial and final tests (Table 2).

Also, we have represented the final data of the criteria for evaluating the level of training of professional competence, the experiment group we can see that the criteria that assess the knowledge of students experiment group at the level of knowledge of basic motor physiological principles and effort classification were capitalized by group of 8,18 . At the same time, the criteria for defining and applying the morphofunctional indices in free state and after physical effort are also represented, which were capitalized with an average per group of 8,2. Regarding the criteria for possessing the physiological aspect of the states of the organism and the restoration processes were appreciated with an average per group of 8,17 .

After analyzing the data provided by the testing of the Experiment Group students to the criteria that assess the 3 levels of appreciation of the integrative competences "to know", "to be able", "to possess" (Table 2), we find significant differences $(\mathrm{P}<0,01-0,001)$. Interpreting the differences between the results obtained at the initial and final stages, by the experiment group, we notice that the " $\mathrm{t} "$ calculation varies between $3,96-4,77$, being higher than the tabular " $t$ ", which proves that the statistical differences obtained are significant.

In Table 1 we have represented the comparative analysis of the experimental data of the indices that represent the level of possession of the professional competence at the initial and final stage of the control and experiment group.

The statistical-mathematical analysis of the general marks obtained by the students of the experiment and control groups at the official exam can be noticed that the average grade of the group at the experiment sample represents a pedagogical category superior by one step compared to the control sample $(\mathbf{9 , 5 8}-\mathbf{8 , 6 1})$, a substantial contribution to the overall success of students in the module "Human physiology and motor activity" (Table 1).

Conclusions: The data analysis and the evaluation of the results of the professional competence training experiment for the two groups, is an opportunity to become aware of important things to streamline the professional competence training process for students in the modern academic environment.

Generalizing the above, it can be stated that the optional module "Human physiology and motor activity" contributes to the formation of professional pedagogical knowledge and skills in future physical education teachers and coaches, at a productive level. 


\section{References:}

1. Guidea N. (1994). Pregătirea viitorilor specialişti din domeniul educaţiei fizice şi sportului. În: Revista „Gymnasium”, nr.10, Bacău, p. 34-39.

2. Gönczi-Raicu M., Aftimiciuc O., Danail S. (2014). Competenţe de coordonare complexă în cadrul activităţii didactice integrative a profesorilor de educaţie fizică. Chişinău: „Valinex” SRL. $160 \mathrm{p}$.

3. Nanu M.C. (2006). Formarea limbajului profesional pentru comunicarea pedagogică la studenţii facultăţilor de educaţie fizică şi sport: Teza de dr. ped. Chişinău. 168 p.

4. Farcaş N. şi D. (1997). Teoria educaţiei şi noţiuni de cercetare pedagogică. Bucureşti: Editura Didactică şi Pedagogică, RA. 135 p.

5. Oprescu V. (1996). Fundamentele psihologice ale pregătirii şi formării didactice. Craiova: Editura Universitaria, p. 68-79.

6. Pâslaru Vl., Cabac V. (coord.), Achiri I. et al. (2002). Evaluarea în învăţământ. Orientări conceptuale. Ghid metodologic. MEŞ. Chişinău: IŞE. 145 p.

7. Regulament Privind Evaluarea Performanţelor Cadrelor Didactice Universitare, p.3.

8. Tomşa N. (2003). Pregătirea studenţilor facultăţilor de educaţie fizică şi sport pentru comunicarea dialogo-didactică: Autoref. tez. dr. în ped. Chişinău: INEFS. 28 p.

9. Timuş M., Danail S., Branişte Gh. (2010). Unele aspecte privind posedarea şi formarea competenţelor limbajului profesional scris la studenţii facultăţilor de educaţie fizică şi sport. În: Ştiinţa culturii fizice, nr. 6/3, p. 5-10.

10. Vlăsceanu L. (1982). Metodologia cercetării sociologice. Bucureşti: Editura Ştiinţifică şi Enciclopedică. 322 p.

11. Афтимичук О.Е. (1998). Формирование ритма дидактического общееня у студентов институтов физической культуры: Дис. ... д-ра пед.наук. Кишинев. 301 с.

12. Александров А.Б. (2008). Информационно-аналитическая система мониторинга здоровья, оценки адаптационного потенциала и риска артериальной гипертензии у студентов вуза: Дис. ...канд.мед.наук. Екатеринбург. 126 с.

13. Адольф В.А., Лукьяненко М.В., Чурляева Н.П. (2011). Количественная оценка компетентности выпускников интегрированной системы обучения и возможности ее повышения. В: Педагогическое образование и наука, №11, с.22 - 30.

14. Байденко В.И., Гришанова Н.А., Пугач В.Ф. (2005). Россия в Болонском прочессе: проблемы, задачи, перспективы. В: Высшее оброзование сегодня, №5, с. 16-21.

15. Данаил С.Н. (1989). Методика подготовки студентов факультетов физического воспитания к коммуникативной дидактической деятельности: Дис. ... канд. пед. наук. Ленинград. 272 с.

16. Данаил С.Н. (2010). Физкультурное образование в контексте современньх разработок теории деятельности и личности. В: Международная научно-практическая конференция государств-участников СНГ по проблемам физической культуры и спорта: доклады плен. заседаний. Минск: БГУФК, с. 228-236. 